\title{
WHY COURTS? COMMENT ON ROBINSON
}

\author{
E. DONALD ELLIOTT*
}

G

LEN RoBinson's suggestion' that courts should award damages to persons exposed to toxic substances before any disease occurs and without proof of causation of injury in the traditional sense is not merely an idle theoretical proposal; it is the direction in which the law of "toxic torts" is now moving.

To be sure, as yet few courts have been willing openly to jettison traditional causation requirements. Rather, the change is being accomplished indirectly under the guise of damages for "cancerphobia,", reimbursement for the costs of future "medical monitoring,",3 judicially stimulated settlements, ${ }^{4}$ and reimbursement for loss of property values. ${ }^{5}$ Together these trends add up to courts and juries straining to nullify the unrealistic hurdle that allowed victims of toxic substances poisoning to

\footnotetext{
* Professor of Law, Yale Law School.

' Glen O. Robinson, Probabilistic Causation and Compensation for Tortious Risk, in this issue.

2 Ayers v. Jackson Township, 189 N.J. Super. 561, 461, A.2d 184, 188-190 (1983) (denying motion for summary judgment and permitting trial on plaintiffs' claims of emotional distress resulting from exposure to water containing cancer-causing substances), rev'd in part and affirmed in part after trial, No. A-2103-83T3 (App. Civ., June 4, 1985) (\$8.3 million verdict for medical monitoring reversed where expert witness unable to "qualify the increased risk" ; $\$ 2.1$ million verdict for emotional distress set aside on grounds of government immunity "although damages for these intangible harms might be recoverable from a nongovernmental entity"; $\$ 5.4$ million for decreased "quality of life" sustained).

${ }^{3}$ See, for example, Askey v. Occidental Chem. Corp., 477 N.Y.S.2d 242, 247 (A.D. 1984) (persons exposed to chemicals may recover for future expense of medical monitoring provided they present expert testimony that such expenditures are "reasonably anticipated").

${ }^{4}$ In re Agent Orange Product Liability Litigation, 597 F. Supp. 740, 857 (E.D.N.Y., 1984) (tentatively approving $\$ 180$ million settlement although "evidence presented .. . to date suggests . . . case is without merit" under existing law).

5 The "precedent"' for the property value approach was set by the government buy-outs of homes near the chemical dump at Love Canal, New York and at Times Beach, Missouri. William R. Ginsberg \& Lois Weiss, Common Law Liability for Toxic Torts: A Phantom Remedy, 9 Hofstra L. Rev. 859, 860 (1981) (describing Love Canal incident).
}

[Journal of Legal Studies, vol. XIV (December 1985)] 
recover only by proving that it is more likely than not that particular physical injuries were caused by exposure to a particular toxic substance. $^{6}$

The traditional legal rule is based on the premise that it is "unfair to require an individual to pay for another's tragedy unless it is shown that it is more likely than not that he caused it,"7 but this principle no longer captures the community's intuitive sense of justice ${ }^{8}$ in cases involving what one judge recently described as the "Frankenstein monster", of toxic chemicals. Therefore, in my opinion, the real question is no longer whether the law will abandon the traditional causal regime in toxic cases, but rather how the law will acknowledge the change and what will replace the traditional standard.

There are essentially four possible answers. (1) We can do nothing and permit the system to evolve by legal fiction ${ }^{10}$ from one that compensates proven injuries to one that compensates exposures as such in the guise of cancerphobia, medical monitoring, and decreased property values; (2) we can follow Glen Robinson's suggestion that courts and juries award damages to individual exposed persons based on an estimate of the probabilities that they will suffer disease or other maladies later in life ${ }^{11}$ (3) we could follow David Rosenberg's suggestion for "public law" class actions to compensate the class of exposed persons as a class; ${ }^{12}$ or (4) we could

${ }^{6}$ See Jackson v. Johns-Manville Sales Corp., 727 F.2d 506, 516 (5th Cir. 1984) (stating traditional rule). The traditional rule is unrealistic in toxics cases because it asks the impossible of science. See Samuel S. Epstein, The Politics of Cancer 38-46 (rev. ed. 1979); William M. Landes \& Richard A. Posner, Tort Law as a Regulatory Regime for Catastrophic Personal Injuries, 13 J. Legal Stud. 417, 423 (1984) (epidemiology speaks to the issue of the incidence of disease in groups, not individual cases).

7 In re Agent Orange Product Liability Litigation, 597 F. Supp. 740, 781 (1984).

${ }^{8}$ Compare E. Donald Elliott, Holmes and Evolution: Legal Process as Artificial Intelligence, 13 J. Legal Stud. 113, 142 (1984) (legal rules record solutions that have been accepted in the past as just).

${ }^{9}$ Kinney v. Scientific, Inc., 15 Envtl. L. Rep. 20403, 20407, slip op. at 21 (N.J. Super. Ct. Middlesex Cty. Law Div., April 3, 1985) ("A company which creates the Frankenstein monster of abnormally dangerous waste should not expect to be relieved of accountability for the depredations of its creature merely because the company entrusts the monster's care to another, even an independent contractor").

${ }^{10}$ The classic work on the use of legal fictions to change the law is Henry Sumner Maine, Ancient Law: Its Connection with the Early History of Society and Its Relation to Modern Ideas, with Introduction and Notes by Frederick Pollock (Raymond Firth ed. 1963) (1st ed. 1861).

11 Robinson, supra note 1 , at 781.

12 David Rosenberg, The Causal Connection in Mass Exposure Cases: A "Public Law" Vision of the Tort System, 97 Harv. L. Rev. 849 (1984). See also in re Agent Orange Product Liability Litigation, 597 F. Supp. at 833-834 (noting that "no individual class member would 
legislate a compensation system for toxics that would rely on institutions other than courts and juries to decide who is entitled to compensation, and how much they should receive. ${ }^{13}$ For the following reasons I favor the fourth alternative, a statutory compensation system.

In evaluating the various alternatives, it is important to keep the factual setting of toxics problems clearly in mind. Robinson implies that the long latency period between exposure and the onset of diseases such as cancer is the chief difficulty in assessing toxic harms. ${ }^{14}$ In fact, however, this is a relatively insignificant aspect of the problem. Usually the failure of identification stems from the lack of records on exposure in the first place, not to the time lag between the exposures and the filing of the lawsuit. ${ }^{15}$ Indeed, in many cases it is actually easier to assess the probable causes of a malady twenty or thirty years later because one has the benefit of the interim advances in scientific research.

The features of toxics problems that are actually of the greatest importance for designing compensation systems are (1) that the high degree of scientific uncertainty typically weakens the association between disease and any particular chemical agent and (2) that persons exposed to the toxic chemical have also typically been exposed to a large number of other potential contributing causes of the disease or malady in question. Together, these two features make it highly doubtful that case-by-case adjudication of claims by courts and juries is a tolerable method of delivering compensation to persons exposed to toxic substances.

The first problem of which Robinson takes insufficient account is the problem of scientific uncertainty. Robinson's proposal depends on juries

\footnotetext{
be able to prove that his or her injuries were caused by Agent Orange," but holding case could proceed on behalf of the class as a whole). In practice, a similar group recovery is often reached in cases that are not formally class actions when the defendant settles for a lump sum and leaves it up to the plaintiffs' counsel to allocate the recovery among individual claimants.

${ }^{13}$ Superfund Section 301(e) Study Group, Injuries and Damages From Hazardous Wastes: Analysis and Improvement of Legal Remedies, Report to Congress in Compliance with Section 301(e) of the Comprehensive Environmental Response, Compensation and Liability Act of 1980 (P.L. 96-510) 97th Cong., 2d Sess. (1982). One model for a statutory compensation system is the Black Lung Program, see John S. Lopatto, The Federal Black Lung Program: A 1983 Primer, 85 W. Va. L. Rev. 677 (1983). Another is the workers' compensation system, see Richard A. Epstein, Manville: The Bankruptcy of Product Liability, Regulation, September/October, 1982, at 14. A third is the Social Security Disability Program, see Jerry Mashaw, Bureaucratic Justice: Managing Social Security Disability Claims (1983).

${ }^{14}$ Robinson, supra note 1 , at 784 .

15 See generally Timothy Atkeson, Toxics Regulation and Products Liability: Decreasing Exposure in the Workplace, Increasing Exposure in the Courts, 13 Envtl. L. Rep. 10418, 10422 (1983).
} 
in individual cases making estimates of the probability that someone will suffer injury in the future as a result of exposure to a particular substance. It is rare indeed that anything like the information base necessary to make even rough probability estimates will exist. ${ }^{16}$ For example, former EPA Administrator William Ruckelshaus relates that when the National Academy of Sciences was asked to estimate the total number of human bladder cancers that would result from seventy years of daily exposure to saccharin, its estimate ranged from less than one case to 1.1 million cases. ${ }^{17}$ As Ruckelshaus noted dryly, such risk assessments are "of limited use to the policymaker." 18 They would be of even less use to juries asked to award damages to individual plaintiffs in "probabilistic causation" tort cases. Society is often willing to make precautionary regulatory decisions based on weak suggestive evidence that a particular substance may cause harm. ${ }^{19}$ It is another matter entirely to invite lay juries to make huge damage awards based on inconclusive animal studies and conclusory expert testimony. ${ }^{20}$

Moreover, case-by-case adjudication through the courts, chemical by individual chemical, is intolerably inefficient and expensive. For example, the Rand Corporation's study of asbestos litigation found that over 60 percent of total costs were expended for administrative costs (primarily attorneys' fees). ${ }^{21}$ In other words, nearly two dollars were spent on lawyers for every dollar of compensation delivered to a victim. Litigating in court, which is expensive in any circumstance, is particularly wasteful when the same scientific issues must be retried over and over again every time a case is brought. ${ }^{22}$ By contrast, in the administrative process, a

\footnotetext{
16 The one exception may be radiation. A relatively precise dose response curve has been constructed for radiation that is accepted by many scientists. See generally National Academy of Scientists, The Biological Effects of Ionizing Radiation (1980). This may help to explain why a probabilistic approach to compensation for exposure to risk was suggested first for radiation areas. Samuel D. Estep, Radiation Injuries and Statistics: The Need for a New Approach to Injury Litigation, 59 Mich. L. Rev. 259 (1960).

17 William D. Ruckelshaus, Risk in a Free Society, 14 Envtl. L. Rep. 10190 , 10191 (1984).

18 Id.

19 See, for example, Ethyl Corp. v. Environmental Protection Agency, 541 F.2d 1 (D.C. Cir. 1976), cert. denied, 426 U.S. 941 (1976).

20 In re Agent Orange Product Liability Litigation, 597 F. Supp. at 781 (noting "fundamental" distinction between quantum of evidence required to support precautionary risk regulation and award of compensatory damages).

21 J. Kakalik, P. Ebener, W. Festiner, \& M. Shanley, Costs of Asbestos Litigation (Rand Inst. Civil Just. 1983) at vii, table S.2 (victims receive only 37 percent of total costs paid by defendants and insurers). See also Walter Y. Oi, Tort Law as a Regulatory Regime: A Comment on Landes and Posner, 13 J. Legal Stud. 435, 439 (1984).

22 Hardy v. Johns-Manville Sales Corp., 681 F.2d 334 (5th Cir. 1982). F. Scott Baldwin, Asbestos Litigation and Collateral Estoppel, 17 Forum 772 (1982) (collateral estoppel generally not available on liability issues).
} 
generic risk assessment could be performed for a number of chemicals simultaneously and the results incorporated into claims decisions in individual cases. ${ }^{23}$

Admittedly, the inherent inefficiencies of traditional litigation as a system for delivering compensation are ameliorated somewhat by class actions. Class actions achieve some economies of scale by grouping together into one case many people (and potentially everyone) who have been exposed to a particular chemical. But with the exception of a few types of occupational exposures (asbestos) or drugs (DES), where exposure to a single substance dominates, most toxic cases involve exposure to many different agents, both natural and chemical, each of which contributes a small additional risk. Unfortunately, the composition of the "risk portfolio" is unique for each individual so that many courts have rightly denied class action status to mass tort claims on the ground that the common issues of fact do not predominate. ${ }^{24}$ Even if a lawsuit proceeds as a class action, however, at most it can only award the proportion of damages attributable to a single substance. In contrast, an administrative rule-making proceeding could assess the relative contributions of a variety of substances and other risk factors to particular diseases.

Not only are there inherent economies of scale in using generic administrative rule making to make risk probability estimates but there is also reason to believe that other institutions are better equipped than lay courts and juries to assess risks. ${ }^{25}$ Administrative agencies are superior to judges in making risk assessment decisions that turn on scientific and technical evidence. ${ }^{26}$ Even more fundamentally, risk regulation raises inherently "polycentric" controversies involving a balancing of multiple interests. The future beneficiaries of a drug such as Bendectin, for example, find it difficult to represent their interest in keeping the drug on the market in an endless procession of tort suits against the manufacturer. ${ }^{27}$

${ }^{23}$ See Heckler v. Campbell, 103 S. Ct. 1952 (1983) (upholding Social Security "grid" regulations for assessing disability).

${ }^{24}$ See In re Northern District of California, Dalkon Shield IUD Products Liability Litigation, 693 F.2d 847, 856 (9th Cir. 1982), cert. denied sub nom A. H. Robbins Co. v. Abed, 459 U.S. 1171 (1983). Other courts have limited class certification to particular issues. See In re Agent Orange Product Liability Litigation, 100 FRD 718, 724 (E.D. N.Y., 1983).

${ }^{25}$ See Peter Huber, Safety and the Second Best: The Hazards of Public Risk Management in the Courts, 85 Colum. L. Rev. 277 (1985); Joel Yellin, High Technology and the Courts: Nuclear Power and the Need for Institutional Reform, 94 Harv. L. Rev. 489 (1981).

26 Ethyl Corp. v. Environmental Protection Agency, 541 F.2d at 66 (Bazelon J., concurring); Sheila Jasanoff \& Dorothy Nelkin, Science, Technology, and the Limits of Judicial Competence, 214 Science 1211 (1981); Lawrence Tribe, Trial By Mathematics: Precision and Ritual in the Legal Process, 84 Harv. L. Rev. 1329 (1971).

27 Huber, supra note 25, at 330, 333 n.196. 
Some contend that administrative compensation systems may be even more inefficient than common-law litigation because of the possibility of "rent-seeking" by beneficiaries. The experience of the federal Black Lung program is generally cited in support of this thesis. There are several answers to this charge. First, the defining characteristic of administrative compensation systems created by statute is that they can be set up in different ways. The Black Lung program is often condemned for paying too much to claimants; the workers' compensation system is condemned for paying claimants too little. The moral is that it is fallacious to dismiss all "administrative" systems because experience with a particular statute is thought to be unsatisfactory. One must analyze the features of each particular statutory structure separately, not lump all "administrative" systems together and reject them out of hand.

More fundamentally, however, it is a mistake to condemn the Black Lung program because it has ended up paying out more money in benefits than its sponsors estimated when the program was enacted. Nor is it necessarily a bad thing that more claims are being paid than originally anticipated. There is an abuse only if persons being compensated could easily be identified as not suffering from Black Lung disease. To put the point more generally, inefficient tort systems suffer from the opposite vice, also difficult to measure, that many persons entitled to compensation go empty-handed because their claims are small and too expensive to prosecute. With expected benefits held constant, a compensation system with lower administrative costs to the claimant should induce an increased number of claims. But that fact alone is not evidence of "rentseeking"; it is equally plausible to treat it as a correction of a misallocation caused by the high administrative costs of the tort system. Finally, the tort system has its own very effective rent seekers-trial lawyers.

In conclusion, I am sympathetic with Robinson's position that compensation in toxic cases should rest on probabilistic evidence. Indeed, even if we retain the tort system for toxic cases, a candid assessment of probabilities of injury based on scientific evidence is superior to the present legal fictions that make compensation turn on cancerphobia, medical monitoring, or reduced property values. ${ }^{28}$ Yet there are important caveats. First, it is far from clear that every risk, however small, should be com-

\footnotetext{
28 Compensating exposures to toxic chemicals via legal fictions results in awards based on public fear. For an account of the factors other than scientific knowledge that may enter into popular fears about chemicals, see generally Mary Douglas \& Aaron Wildavsky, Risk and Culture (1982). Compare Metropolitan Edison Co. v. People Against Nuclear Energy, 460 U.S. 766, $103 \mathrm{~S}$. Ct. 1556 (1983) (psychological harm resulting from public fear is not an environmental impact which must be considered under the National Environmental Policy Act).
} 
pensated. Robinson's system could accommodate a de minimis exception, ${ }^{29}$ and one should be added. Second, and more fundamental, Robinson's proposal strikes me as unsound because it is wedded to the traditional tort system. Robinson's argument follows the usual pattern of what I call "goal analysis.", 30 It abstracts and extends goals from an existing body of law without paying sufficient attention to the institutional setting. The shift from the traditional causal standard of "more likely than not" to probabilistic risk assessment calls for an administrative setting in which institutions and procedures can be designed to fit the problem.

Complex technical issues of risk assessment should not be left to trial lawyers, judges, and juries.

29 See, for example, Monsanto Co. v. Kennedy, 613 F.2d 947 (D.C. Cir. 1979); FDA De Minimis Policy for Carcinogenic Residues in Food-Producing Animals, 44 Fed. Reg. 17070 (March 20, 1979).

${ }^{30}$ E. Donald Elliott, Goal Analysis versus Institutional Analysis of Toxic Compensation Systems, 73 Geo. L. J. 1357 (1985). 
